\title{
Ağaçlandırma ve doğal gençleştirme yoluyla kurulmuş kızlçam meşcerelerinin yapısal özellikleri
}

\author{
Ulaş Yunus Özkan ${ }^{a, *}$, İbrahim Özdemir ${ }^{b}$
}

\begin{abstract}
Özet: Akdeniz bölgesinde, doğal gençleştirme ve ağaçlandırma yoluyla kurulan genç kızılçam meşcerelerin yüzölçümü giderek artmaktadır. Kızılçam orman ekosistemlerinde, etkili bir karbon ve biyolojik çeşitlilik yönetimi için, yeni kurulan bu meşcer elerin yapısal özellikleri, yaşlı doğal meşcereler göz önünde bulundurularak değerlendirilmedir. Bu çalışmada; i) doğal gençleştirme ve ağaçlandırma yoluyla kurulmuş olan benzer yaşlardaki meşcerelerin yapısal özelliklerinin karşılaştırılması, ii) meşcere yapısal özelliklerinin süksesyon evrelerine göre eğiliminin belirlenmesi ve bu eğilimin doğal meşcere özelliklerine benzerliğinin ortaya koyulması amaçlanmıştır. Yükselti, bakı, arazi eğimi ve anakaya bakımından benzer olan 8 farklı meşcere grubu tespit edilmiştir. Her meşcere grubundan 5 örnek meşcere seçilmiştir. Bu meşcereler içinde rasgele konumlandırılan 5 örnek alanda, meşcere özellikleri ile ilgili ölçüm ve gözlemler yapılmıştır. Meşcere yapısal özellikleri olarak; göğüs yüzeyi ( $\left.\mathrm{m}^{2} / \mathrm{ha}\right), \mathrm{meşcere} \mathrm{hacmi}$ $\left(\mathrm{m}^{3} / \mathrm{ha}\right)$, kapalılık derecesi (\%), döküntü miktarı (ton/ha), humus (ton/ha), üst topraktaki karbon (C) oranı (\%), kalın ölü odun miktarı $\left(\mathrm{m}^{3} / \mathrm{ha}\right.$ ), ince ölü odun miktarı (ton/ha) ve odunsu tür zenginliği kullanılmıştır. Çalışmada gençleştirme ve ağaçlandırma faaliyetlerinin, kızılçam orman ekosistemlerine hem olumlu hem de olumsuz etkilerinin olduğu tespit edilmiştir. Her ne kadar genç meşcerelerin yapısal özelliklerindeki yaşa bağlı trend, yaşlı meşcerelerle olan farkı kapatabilecek gibi görülse de, döküntü ve humus miktarı ve üst topraktaki $\mathrm{C}$ oranı gibi özelliklerin normale dönmesi için daha uzun süreye ihtiyaç bulunmaktadır. Ağaçlandırma çalışmaları, odun üretimi ve orman ekosistemlerinde tutulan karbon miktarının arttırılmasına önemli katkılar yapmaktadır. Fakat bu faaliyetler, yaban hayvanları için önemli habitatları barındıran çalılık alanların azalmasına yol açmak tadır. Sonuç olarak, yoğun odun işletmeciliği yapılan kızılçam ormanlarında, yeterli miktarda doğal yaşlı meşcere ve makilik alanlar dokunulmadan birakılmalidır.
\end{abstract}

Anahtar kelimeler: Karbon, Biyolojik çeşitlilik, Döküntü, Humus, Ölü odun

\section{Structural characteristics of planted and naturally regenerated brutian pine stands}

\begin{abstract}
The acreage of secondary brutian pine (Pinus brutia Ten.) stands established both nat urally following clearcutting and reforestation planting increases over the forest landscapes in the Mediterranean Region. Considering natural mature stands, $t$ he structural characteristics of these secondary stands should be assessed for an efficient carbon and biodiversity management in the brutian pine ecosystems. The aim of this study is to i) compare some structural attributes of the reforestation plantings and naturally regenerated stands of brutian pine in similar age and ii) to determine the trends in features regarding stand structures of reforestation and naturally regenerating stands with regard to successional stages and their convergence towards natural stand conditions. We identified eight different aged stand groups that are similar with respect to altitude, aspect, slope, soil parent material. Five stands were selected from each group. Then, 5 sampling plot randomly located were measured for each stand. Within each sample plot, we measured and calculated the attributes fallo wing; basal area $\left(\mathrm{m}^{2} / \mathrm{ha}\right)$, stem volume ( $\left.\mathrm{m}^{3} / \mathrm{ha}\right)$, canopy caver percentage (\%), litter (ton/ha), humus (ton/ha), carbon (C) ratio in topsoil (\%), coarse woody debris ( $\mathrm{m}^{3} / \mathrm{ha}$ ), fine woody debris (ton/ha), and woody species richness. In conclusion, we can say that regeneration and reforestation practices have both positive and negative impacts on brutian pine forest ecosystems. Although the young stands showed evidence for convergence towards the conditions found in the old mature stands, more time are necessary for some attributes such as litter amount, humus, and $\mathrm{C}$ ratio in topsoil. Reforestation planting has a positive effect on wood production and carbon accumulation in the brutian forest ecosystems. However, it causes a decrease in the shrub lands providing important habitats for wild animals. This study suggests that a sufficient amount of old mature stands and maquis-type shrublands should be preserved intact in the heavily managed brutian pine forests.
\end{abstract}

Keywords: Carbon, Biodiversity, Litter, Humus, Dead wood

\section{Giriş}

Orman ekos is temlerinde biyolojik çeşitliliğin korunması ve zenginleştirilmesinde, meşcere yapısı önemli bir faktör olarak görülmektedir (Deal, 2007; Özkan, 2010). Meşcere yapısı; ağaç tepelerinin tabakalanma durumu, devrik ölü odun miktarı, döküntü tabakası kalınlığı, üst toprak horizonundaki organik madde miktarı, yaban hayvanları için besin ve örtü değeri taşıyan meyveli çalı türlerinin sayısı gibi unsurlarla ifade edilmektedir (McElhinny vd. 2005). Siralanan bu mikro-habitat özellikleri bakımından zengin $\square \quad$ a İstanbul Üniversitesi, Orman Fakültesi, Orman Amenajmanı Anabilim Dalı, 34473, İstanbul

${ }^{\text {b }}$ Süleyman Demirel Üniversitesi, Orman Fakültesi, Yaban Hayatı Ekolojisi ve Yönetimi Bölümü, 32260, Isparta

@ * Corresponding author (İletişim yazarı): uozkan@istanbul.edu.tr

$\checkmark$ Received (Geliş tarihi): 11.01.2016, Accepted(Kabul tarihi): 29.03.2016
Citation (Attf): Özkan, U.Y., Özdemir, İ., 2016. Ağaçlandırma ve doğal gençleştirme yoluyla kurulmuş kızılçam meşcerelerinin yapısal özellikleri. Turkish Journal of Forestry, 17(2): 118-124.

DOI: $10.18182 /$ tif. 60167 
olan bir meşcere, “yapıs al çeşitliliği yüks ek meşcere” olarak tanımlanmaktadır.

Ülkemizdeki kızılçam ormanlarında son 50 yıldır uygulanan odun üretimi faaliyetlerinin, orman yapısinı homojen hale getirdiği düşünülmektedir. Bu uygulamaların kızılçam ekosistemlerinde habitat kayıplarına yol açtığı ve bundan bitki ve hayvan türlerinin olumsuzyönde etkilendiği yönünde, meslek kamuoyunda ciddi endişeler bulunmaktadır (Odabaşı ve Özalp, 1994; Oğurlu, 2008; Akdemir ve Özdemir, 2015). Kızılçamın biyolojisi gereği aynı yaşlı ve maktalı ormanlar kurmaktadır. Geniş alan tıraşlama kesimleri ile bir maktaya doğal yöntemlerle gençlik getirilmekte ve düzenli bakım müdahaleleri ile idare süresi sonunda kaliteli tomruk üretimi amaçlanmaktadır. İşletmecilik faaliyetleri meşcere yapısını iki yönde etkilemektedir. Bunlardan ilki, tıraşlama kesimleri sonucunda, küçük arazi parçaları (meşcere içi boş luklar, çalı kümeleri, diğer ağaç türlerinin küçük grupları vb.) makta içinde erimektedir. Böylece yatay arazi çeşitliliğinde (meşcere ve diğer parçalarının çeşitliliği) bir azalma meydana gelmektedir. İkinci olarak, yaşlı meşcerelerde görülen özellikler (tepesi kırık ağaçlar, dikili kurular, ölü odunlar, çalı türleri, kovuk ağaçlar vb.) kurulan genç meşcerelerde azalmaktadır. Ayrıca, bakım kesimleri olarak adlandirılan gençlik, sıklik ve aralama kesimleriyle, meşcerelerdeki bazı mikro-habitatlar (örn; dikili kuru, diğer yapraklı türler vb.) zarar görebilmektedir.

Doğal gençleştirme ve ağaçlandırma uygulamalarının biyolojik çeșitliliğ e etkisini inceleyen çok sayıda çalışma bulunmaktadır. Örneğin, Halpern vd. (1995) istihsalden sonra doğal gençleştirme sahalarında damarlı bitki çeşitliliğinin, tepe kapalılığ 1 oluşmadan önce orijinal seviyesine (kesimden önceki) ulaşabildiğini, diğer taraftan kontrollü yakma yapılan sahalarda ise bitki çeşitliliğ inin ilk 20 yıl boyunca düşük olduğunu ve bazı türlerin alandan çekildiğini belirtmişlerdir. Benzer bir çalışmada, Lust vd. (1998) doğal gençleştirmeden sonra ilk yaş sınıflarında otsu bitki çeşitliliğinin düşük olduğunu ve ileri yaşlara (son yaş sınıflarında) doğru çeşitliliğin giderek artığını tespit etmişlerdir. Gerzon vd.(2011) tarafindan Kanada'da yapılan çalışmada, genç meşcerelerin yapısal özelliklerinin yaklaşık 112. yıllarda "doğal yaş lı orman" özelliklerine benzemeye başlı̆̆ını tespit etmişlerdir. Ancak, tüm özellikler bakımından doğal yaşlı orman şartlarına 200 ve hatta 250 . yaşlarda ulaşılabileceğini belirtmişlerdir. Aynı yaşlardaki ağaçlandırma sahaları ve doğal meşcerelerin kıyaslandığ çalışmalar da yapılmıştır. Örneğin; Lugo (1992) tarafindan yapılan çalışmada; ağaçlandırma yoluyla kurulan meşcerelerde, alt tabakadaki bitki çeşitliliğinin 50 yılda kendi yaşındaki doğal gençleştirme sahalarına eșitlenebildiği ortaya koyulmuştur.

Ülkemizde, genç kızılçam meşcerelerinin doğal ya da yapay yöntemlerle kurulduğundan itibaren, meşcere yapısal özelliklerinin yaşa bağlı olarak nasıl bir değişim gösterdiğiyle ilgili bir araştırma bulunmamaktadır. Doğal gençleştirme yapılmadan önceki yaşlı meşcere yapısının tekrar elde edilip edilemeyeceği ya da yeni kurulan meşcerenin zamana bağlı olarak doğal yapıya ne derece yaklaşabildiği bilinmemektedir. Aynı şekilde ağaçlandırmaya konu olan bozuk kızılçam meşcerelerinde ve maki sahalarında, ağaçlandırma çalışmalarından sonra hangi yapısal unsurların değiștiği ile ilgili literatürde bir değerlendirme yoktur. Yine ağaçlandırma yoluyla kurulan kızılçam meşcerelerinin yapısal özelliklerinin, normal kapalılıktaki yaşlı kızılçam meşcerelerinin temsil ettiği yapıya ne ölçüde benzeştiği ile ilgili zaman-seri analizi bulunmamaktadır. Bunların yanında, ağaçlandırma ve doğal gençleştirme ile elde edilmiş benzer yaştaki meşcereler arasında, yapısal özellikler bakımından bir fark olup olmadığı da incelenmemiştir. Kızılçam ormanlarında uygulanan işletmecilik faaliyetlerinin etkisi daha iyi anlaşılması ve odun üretimi ile biyolojik çeșitliliğin korunması arasında uygun bir denge sağlanabilmesi amaciyla, yukarıda siralanan değerlendirmelerin yapılmasının önemli olduğu düşünülmektedir.

Sonuç olarak sunulan bu çalışmada, yapay ve doğal yöntemlerle kurulan kızılçam meşcerelerinin yapısal özelliklerinin yaşa bağlı olarak ortaya koyulması ve [bu] bunların kısmen müdahale görmüş yaşlı meşcerelerin özellikleriyle karşılaştırılması amaçlanmıştır. Böylece yapay/doğal gençleștirme çalışmalarının ve ardından bu genç meşcerelere uygulanan silvikültürel müdahalelerin karbon birikimi ve biyolojik çeşitliliğe etkileri değerlendirilmiştir.

\section{Materyal ve yöntem}

\section{1. Çalışma alanı}

Çalışma, yoğun işletmecilik faaliyetlerine konu olan Isparta Orman Bölge Müdürlüğüne bağll, Aşağıdökdere, Çandır ve Melli Orman İşletme Şefliklerinde yürütülmüştür. Diğer çevresel faktörlerin etkisini en aza indirmek ve örnek alanlar arasında bir standart sağlamak amacıyla, örnek alanlar; 330-420 m yükseltiler arasında, anakayanın kireç taş1 olduğu, arazi eğiminin \%20-30 arasında değiștiği ve kuzey-batı yamaçlardan alınmıştır.

\section{2. Örnek alanlar}

Hem ağaçlandırma hem de doğal gençleştirme sahalarının üç farklı yaş grubundan örnek alanlar alınmıştır. Ayrıca, karşılaştırmaya temel oluşturmak amaciyla, ağaçlandırma ve doğal gençleştirmeye konu olan, normal kapalılıktaki (\%70-100) yaşı kızılçam ve bozuk (kapalılık<\% 10) kızılçam meşcerelerinden ölçme ve gözlemler yapılmıștır. Çalışma alanında, uluslararası anlamda hiçbir insan müdahalesine konu olmayan "doğal yaşlı orman" kavramına karşıllı gelen çok yaşlı meşcere bulunmamaktadır. Bu sebepten seçilen yaşlı (yaklaşı 110 yaşındaki) kızılçam meşcerelerine geçmişte kısmen müdahalelerin yapılmış olma ihtimali göz $\operatorname{ard}_{1}$ edilmemelidir. Sonuç olarak, bu çalışma hem ağaçlandırma hem de doğal gençleștirme sahalarında dört farkı yaş grubunun $(11-14 ; 18-23$; 29-35; 87-118) her birinden 5'er örnek alan alınarak, toplamda 40 örnek alanda yürütülmüştür. Anakaya, yükselti, arazi eğimi ve bakı faktörlerinin standart tutmak amaçlandığından, özellikle 40 yaşının üstündeki yapay ya da doğal yöntemlerle kurulmuş olan yaş gruplarından yeterliörnek alan bulunamamıştır. Bu yüzden, örneklenen yaş grubu sayısını daha fazla arttırmak mümkün olmamıștır. 


\subsection{Meşcere yapısal özellikleri}

Çalışmada kullanılan meşcere yapısal özellikleri ve hes aplama yöntemleri aşağıda verilmiştir.

\subsubsection{Kapalılı (\%), göğ̈̈s yüzeyi $\left(\mathrm{m}^{2} / \mathrm{ha}\right), \operatorname{hacim}\left(\mathrm{m}^{3} / \mathrm{ha}\right)$}

İlk yaş grubundan (11-14) $200 \mathrm{~m}^{2}$ ve son yaş grubundan (87-118) $600 \mathrm{~m}^{2}$ büyüklüğünde örnek alanlar alınmıştır. Diğer iki yaş gruplanı (18-23 ve 29-35) için $400 \mathrm{~m}^{2}$ büyüklügünde örnek alanlar kullanılmıştır. Örnek alan içine giren tüm ağaçların çapları ölçülmüştür. Buna göre göğüs yüzeyi hesaplanmıştır. Kapalılık, her örnek alanda 5 farklı noktada "KüreselDensitometre" cihazı kullanılarak yapılan ölçmelerin ortalaması alınarak belirlenmiştir.

Örnek alanların kabuklu gövde hacmini hesaplamak için "Weise Orta Ağacı Çapı" ve buna karşılık gelen üç ağaç için ölçülen boy kullanılmıştır. Normal kuruluştaki eşit yaşlı saf meşcerelerde "hacim orta ağacı" çapının; ince ağaçlardan kalın çaplara gidildiğinde, birey sayıs ının yaklaşık \%60'ına rastladığ1 belirtilmektedir (Eler, 2003). İşte, Weise Orta A ğacı Çapı; ince çap kademelerinden başlanıp, kalın çap kademelerine doğru ağaç sayıları toplanarak gidildiğinde, \%60 denk gelen çaptır (Fırat, 1973). Çalışmada her örnek alan için; bu çap değeri ve buna karşılık gelen boy esas alınarak, çift girişli hacim tablosundan hacim değeri hes aplanmış ve bu miktar ağaç sayısı ile çarpılmak suretiyle kabuklu gözde hacmi bulunmuştur.

\subsubsection{Döküntü tabakası (ton/ha)}

Döküntü tabakasının miktarı (ölü yaprak, tohum, çiçek, kabuk, liken, ince dal $<2 \mathrm{~cm}) 30$ x $30 \mathrm{~cm}$ büyüklüğünde 5 alt-örnek alanda tespit edilmiştir. Bu tabaka, zeminin en üstünde kalan, parçalanmanın başlamamış olduğu veya çok az görüldügü bir katmandır ve ağırlıklı olarak son yıllara ait yapraklardan oluşmuştur. Alt-örnek alanların birisi örnek alan merkezinde, diğ erleri ana yönlerde merkezden $6 \mathrm{~m}$ uzaklıkta alınmıştır. Beş alt-örnek alandan toplanan döküntü, $65^{\circ}$ firında 48 saat bekletilmiş ve hektardaki firın kurusu döküntü miktarı hesaplanmıştır.

\subsubsection{Humus ve çürüntü tabakası (ton/ha)}

Bu tabakanın örneklenmesi döküntü tabakasında olduğu gibi yapılmıştır. Alt örnek alanlarda, çürümeye başlamış materyal ve humus tabakası dikkatli biçimde toplanmıştır. Ne kadar dikkatli olunursa olunsun, bu tabakaya bir miktar mineral toprağın karışması engellenememiştir. Bu sebeple, bunlar pülverizatör ile iyice karıştırılarak toz haline getirilmiştir. Ateşte kayıp yöntemiyle organik materyal uzaklaştırılmış ve böylece mineral madde miktarı tespit edilmiştir. Aradaki fark yardımıla, organik madde miktarı hesaplanmıştır.

\subsection{4. Üst toprak tabakasındaki C miktarl (\%)}

Aynıalt örnek alanlarda, humus tabakasının altında yer alan 0-5 cm derinlikteki mineral topraktan örnekler toplanmıştır. Bunlar kurutulmuş ve toz haline getirilmiştir. Daha sonra $2 \times 2 \mathrm{~mm}$ gözenekli bir elekten geçirilerek, ince kökler ve diğer organik materyal temizlenmiştir. Sonra yakma yöntemiyle, karbon yüzdesi (\%) hesaplanmıştır.

\subsubsection{Kalın ölü odun miktarl $\left(\mathrm{m}^{3} / \mathrm{ha}\right)$ ve ince ölü odun miktarl (ton/ha)}

Örnek alan içine giren, ince ölü odun miktarı $(>2 \mathrm{~cm}$ ve $<10 \mathrm{~cm}) 1$ x $1 \mathrm{~m}$ büyüklüğünde 5 alt-örnek alanda belirlenmiştir. Alt-örnek alanların birisi örnek alan merkezinde diğerleri ana yönlerde merkezden 6 muzaklıkta alınmıştır. Toplanan materyal hava kurusu olarak tartılmıştır. Daha sonra yaklaşık yarım kg odun alınarak, bunun firın kurusu ağırlı̆̆ tes pit edilmiştir. Firın kurusu ağırlık, hava kurusu ağırlığa bölünmek suretiyle elde edilen oran kullanılarak her örnek alan için firın kurusu ağırlık hesaplanmıştır. Diğer taraftan, kalın ölü odunların (ortasındaki kalınlığ $>10 \mathrm{~cm}$ ) hacminin belirlenmesi amacıyla; ince ve kalın uçtaki çapları ve uzunlukları ölçülmüştür. Smalian formülü kullanılarak hacimleri hesaplanmış ve toplamları alınarak her örnek alandaki "kalın ölü odun hacmi” bulunmuştur.

\subsubsection{Odunsu bitki tür zenginliği}

Örnek alan içine giren odunsu bitki türleri teşhis edilmiştir. Daha sonra ilgili yaş grubunun beş örnek alanında toplambitki türü sayısı hesaplanmıştır. Bu rakamın örnek alan sayısı olan 5'e bölünmesiyle de "ortalama odunsu tür zenginliği’’ bulunmuştur.

\section{Bulgular}

Klasik meşcere özellikleri için elde edilen bulgulara (Şekil 1) bakıldığında; doğal gençleştirme sahalarında kapalılığın biraz daha erken yaş larda oluşmaya baş ladığı ve yaklaşık otuzuncu senede doğal gençleştirme ve ağaçlandırma sahalarında kapalılığın birbirine eşitlendiği $(\sim \% 80)$ anlaşılmaktadır. Göğüs yüzeyinin de, her iki gençleştirme yöntemi için, ilk otuz yıl içinde kapalılı̆ga benzer bir eğilim gösterdiği görülmektedir. Meşcere kapalılığ1 yaklaşık 110 yaşındaki doğal meşcerelerde \%75 civarındadır. Diğer meşcere özelliklerinden meşcere hacminin, ağaçlandırma ve doğal gençleştirme sahalarında yaşa bağlı olarak benzer bir eğilim gösterdiğive yaş lı doğal meşcere hacmine $\left(\sim 400 \mathrm{~m}^{3} / \mathrm{ha}\right)$ daha erken yaşlarda ulaşabileceği görülmektedir. Ağaçlandırmaya konu olan bozuk kızılçam meşcereleri ile kıyaslandı̆̆ında, 30. yaşlardaki ağaçlandırma sahalarının yaklaşık $130 \mathrm{~m}^{3} / \mathrm{ha}$ daha fazla hacim taşıdı̆̆ 1 tespit edilmiştir.

Yaprak, tohum, çiçek ve ince dal parçalarından oluşan “döküntü” tabakası ve humus tabakas indaki organik madde miktarının, ağaçlandırmalara oranla, doğal gençleştirme sahalarında ilk otuzyılda daha fazla olduğu tespit edilmiştir. Ağaçlandırma sahalarındaki döküntü miktarında, her ne kadar yaklaşık 10 yıllık bir fark bulunsa da, bu açığın ileriki yıllarda kapanabileceği öngörülmektedir. Grafikteki (Şekil 2) eğilim esas alındığında, yaşı doğal kızılçam meşcerelerinde tespit edilen döküntü ve humus tabakalarındaki organik madde miktarının ( 22 ton/ha), hem ağaçlandırma hem de doğal gençleştirme sahalarında ileri yaşlarda oluşabileceği anlaşılmaktadır. Fakat bunun için en azından 70-80 yıl geçmesi gerektiği söylenebilir. Bozuk meşcereler ile kıyas landığında, zeminde biriken döküntü ve humus tabakalarındaki organik madde miktarı bakımından otuzuncu yaştaki ağaçlandırma sahalarında önemli bir artış göze çarpmaktadır ( $\sim 5$ ton/ha). 
Diğer yandan, üst mineral toprak tabakas indaki karbon miktarının oranı $(0-5 \mathrm{~cm})$ bakımından ağaçlandırma ve doğal gençleştirme yoluyla meydana getirilen meşcereler arasında daha fazla fark bulunduğu görülmektedir. Bozuk kızılçam meşcereleri ile kıyaslandığında, her ne kadar ağaçlandırma yoluyla kurulmuş meşcerelerde bir iyileşme ( \%2) bulunsa da, bunların kendi yaşındaki doğal gençleş tirme sahalarından daha düşük karbon yüzdesine ( \%4) sahip olduğu görülmektedir. Grafikteki eğilime bakıldığında (Şekil 2), yaş lı doğal meşcerelerde tespit edilen üst topraktaki karbon yüzdesine $(\sim \% 16)$, doğal gençleştirme yoluyla elde edilen meşcerelerin daha hılı ulaşılabileceği görülmektedir. Bozuk kızılçam sahalarının ağaçlandırması ile kurulan meşcerelerin ise biraz gecikmeyle de olsa, normal değerlere yaklaşabileceği öngörülmektedir.

Şekil 3'deki grafikte, kalın odun enkazının, ağaçlandırma yöntemiyle kurulan genç meşcerelerde (30 yı1), yaşlı bozuk kızılçam meşcerelerinde ve doğal gençleştirme yoluyla kurulan meşcerelerin ilk yıllarında (20 yıl) bulunmadığı görülmektedir. Doğal gençleştirme ile elde edilen yaklaşı $\mathrm{k}$ 30-35 yaşlarındaki meşcerelerde ve yaşlı doğal meşcerelerde ise çok küçük miktarlarda da olsa (sırasiyla; $\sim 0,5 \mathrm{~m}^{3} /$ ha ve $0,8 \mathrm{~m}^{3} / \mathrm{ha}$ ) kalın odun enkazına rastlanmıştır. Diğer taraftan, kesim artıklarının etkisiyle doğal gençleştirme yoluyla elde edilen genç meşcerelerde ince odun enkazı miktarının yirminci yaşlarda en fazla olduğu göze çarpmaktadır $\left(\sim 1,5 \mathrm{~m}^{3} / \mathrm{ha}\right)$. Grafik incelendiğinde, sıklık ve aralama kesimlerinin başlamasıyla bu miktarın biraz daha arttığı 1 e daha sonra meşcere yaşına bağlı olarak düşmeye baş ladığı anlaşılmaktadır. Benzer bir eğilim gösteren, ağaçlandırma yöntemiyle kurulmuş meşcerelerde de, sıklık ve aralama kesimleri sebebiyle yirminci yaşlara doğru ince odun miktarında bir artış $(\sim 1$ $\mathrm{m}^{3} /$ ha) olmakta ve daha sonraki yıllarda benzer şekilde bir düşüş gözlemlenmektedir.

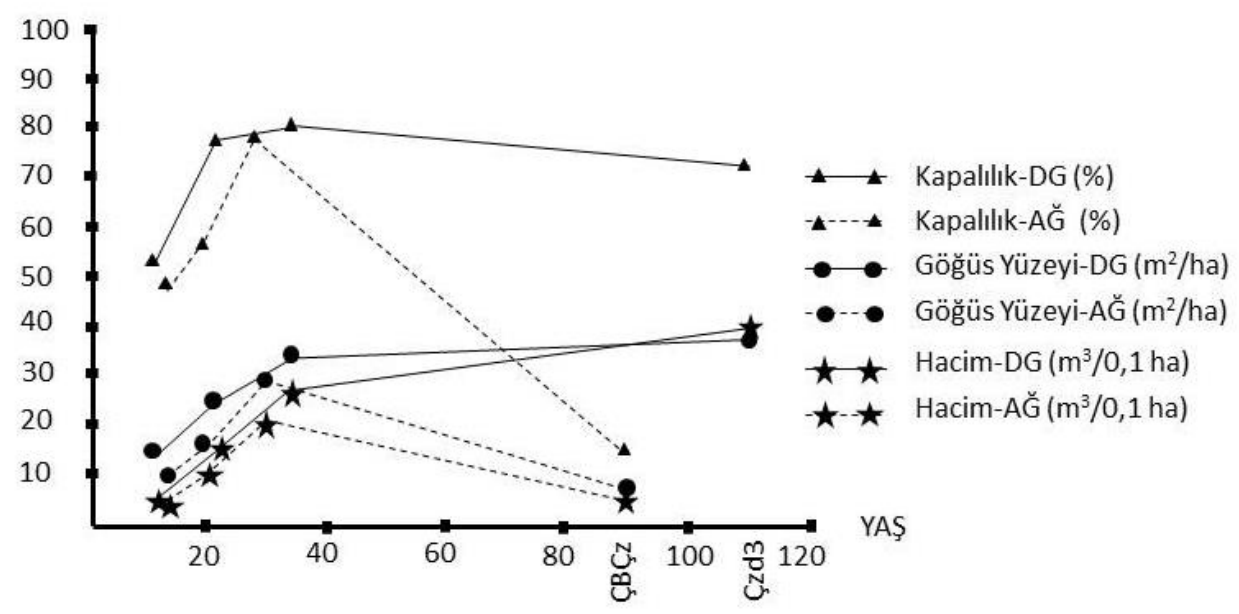

Şekil 1. Kapalılık, göğüs yüzeyi ve hacmin incelenen meşcere grupları itibariyle değişimi (DG; Doğal gençleştirme yöntemiyle kurulmuş meşcereler, AĞ; Ağaçlandırma yöntemiyle kurulmuş meşcereler)

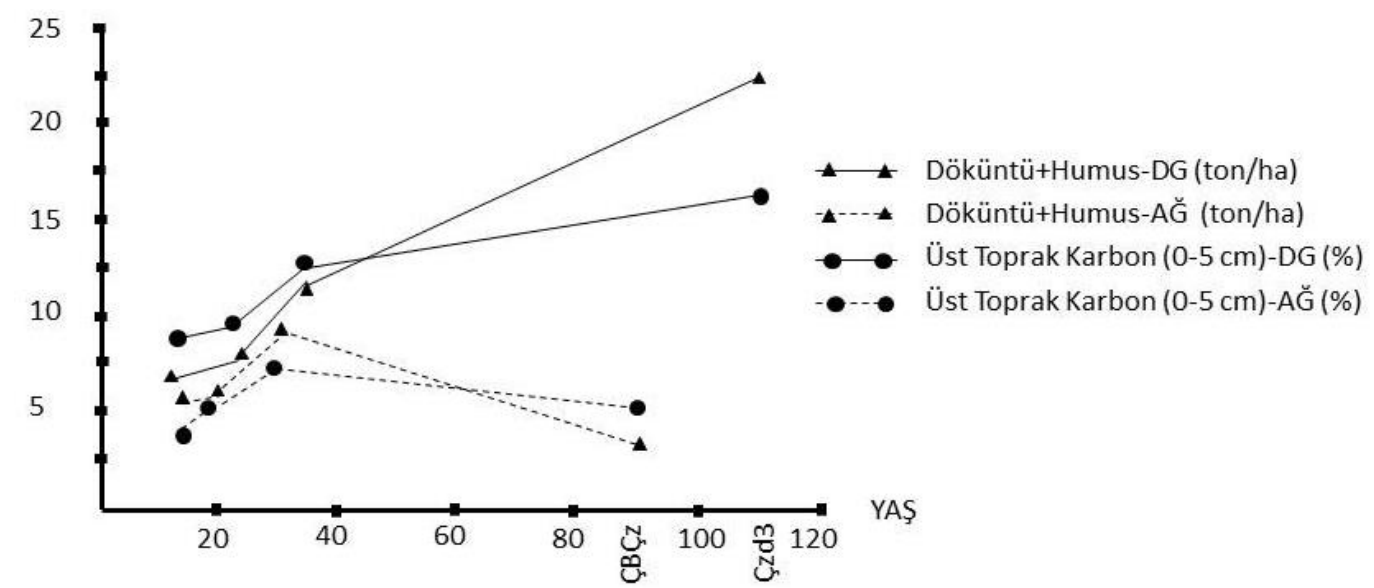

Şekil 2. Döküntü + humus ve üst topraktaki karbon oranının incelenen meşcere grupları itibariyle değişimi (DG; Doğal gençleştirme yöntemiyle kurulmuş meşcereler, AĞ; A $\breve{g}$ açlandırma yöntemiyle kurulmuş meşcereler) 
Örnek alanlarda toplam 17 odunsu bitki türüne rastlanmıștır. Bunlar; Quercus coccifera, Arbutus andrachne, Pistacia terebinthus, Styrax officinalis, Cistus creticus, Myrtus communis, Phillyrea latifolia, Prunus ssp, Crataegus ssp., Olea europaea, Paliurus spina-christi, Quercus infectoria, Ceratonia siliqua, Juniperus oxycedrus, Cercis siliquastrum, Celtis australis, Fontanesia philliraeodies türleridir. En fazla odunsu bitki türü, doğal gençleştirmeyle kurulan ve kapalılı̆̆ın henüz oluşmadığ 110 yaşındaki genç meşcerelerde (12 adet) ve yaşlı bozuk kızılçam meşcerelerinde (13 adet) tespit edilmiştir. Şekil 4'de, meşcere kapalılığının \%50'lere ulaşmasıyla birlikte, genç meşcerelerdeki odunsu tür zenginliğinde belirgin bir düşüş olduğu görülmektedir. Hem ağaçlandırma hem de doğal gençleştirme yoluyla kurulmuş olan 20-35 yaşındaki genç meşcerelerdeki odunsu tür sayısı ile yaşlı doğal kızılçam meşcerelerindeki tür sayıs ının yaklaşık olarak aynı olduğu anlaşılmaktadır. Her yaş gruba ait beş örnek alanın ortalamasının alınması suretiyle hesaplanan "ortalama odunsu tür zenginliğinin" de benzer bir eğilim gösterdiği görülmektedir.

\section{Tartışma ve sonuç}

$\mathrm{Bu}$ çalışma, odun üretimi eksenli bir işletmeciliğin, kızılçam orman ekosistemlerinde meydana getirdiği etkileri anlamak amacıyla gerçekleştirilmiştir. Bu amaçla, hem bozuk kızılçam sahaların ağaçlandırılması suretiyle, hem de yaşlı doğal kızılçam meşcerelerin doğal yöntemlerle gençleştirilmesiyle kurulmuş olan genç meşcerelerin yapısal özellikleri incelenmiştir. İlk olarak değişik yaşlardaki genç meşcerelerin yapısalözelliklerinin yaşa bağlı trendinin, yaşı doğalmeşcerelerin yapısalözelliklerine ne ölçüde yaklaştığı ortaya koyulmuştur. Ayrıca, bu iki farklı yöntem kullanılarak oluşturulan yeni meşcerelerin yapısal özellikleri bakımından farkları belirlenmiştir.

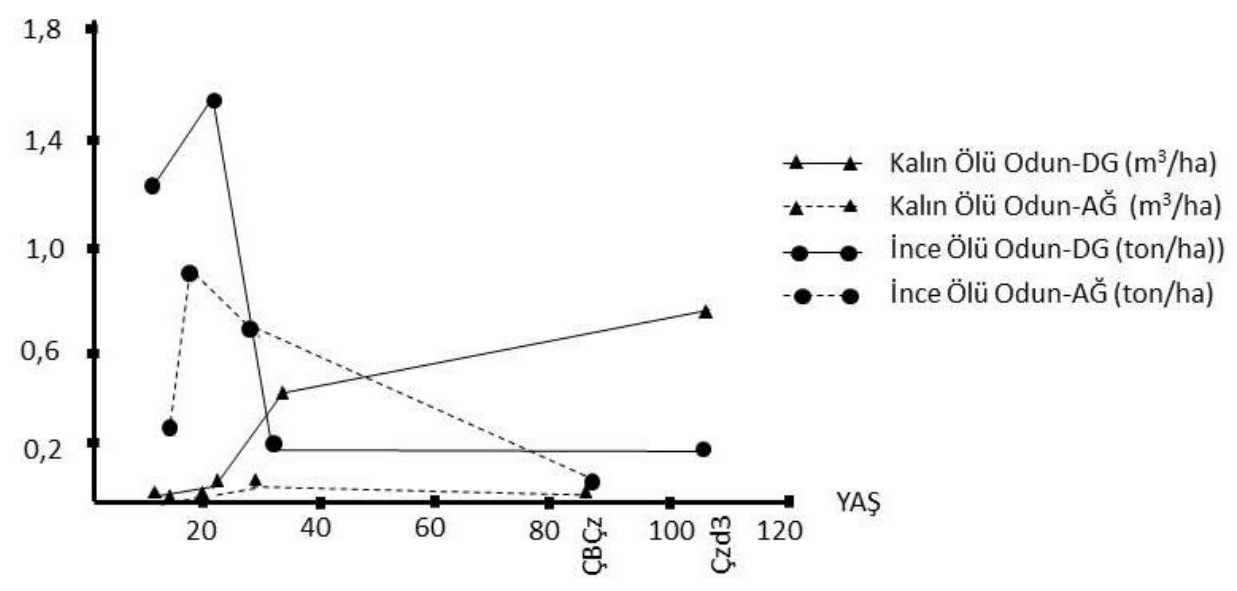

Şekil 3. Kalın ve ince ölü odun miktarının incelenen meşcere grupları itibariyle değişimi (DG; Doğal gençleştirme yöntemiyle kurulmuş meşcereler, A $\breve{G}$; A ğaçlandırma yöntemiyle kurulmuş meşcereler)

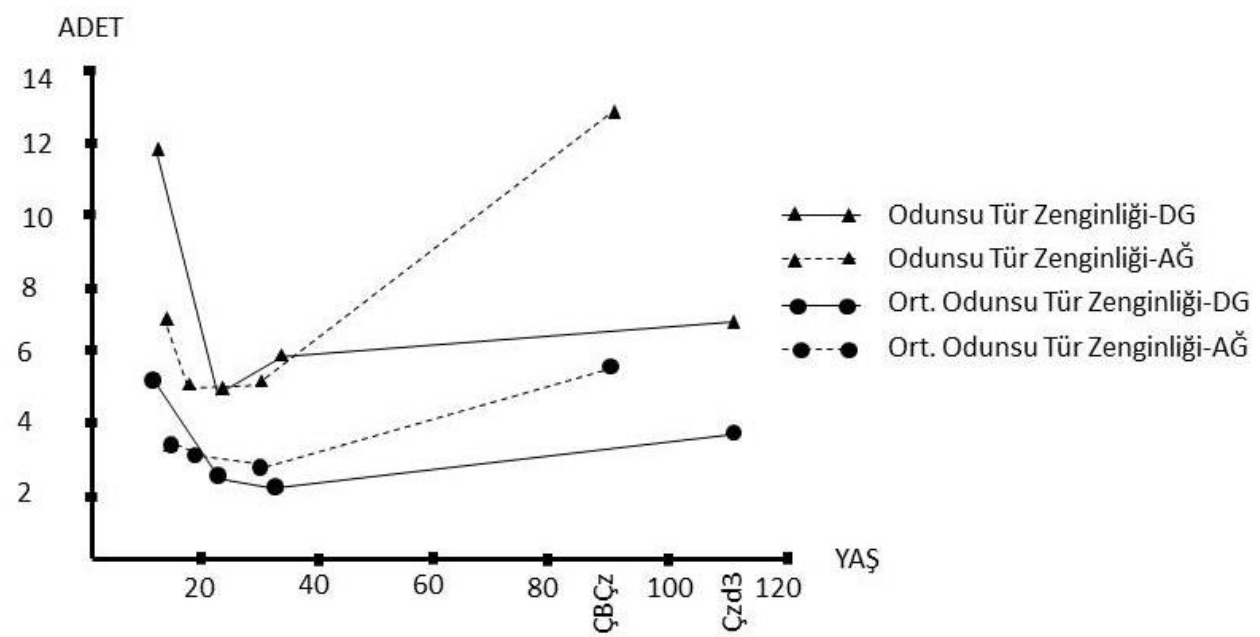

Şekil 4. Odunsu tür zenginliği ve ortalama odunsu tür zenginliğinin incelenen meşcere grupları itibariyle değişimi (DG; Doğal gençleştirme yöntemiyle kurulmuş meşcereler, AĞ; A ğaçlandırma yöntemiyle kurulmuş meşcereler) 
Çalışma bulgularına göre; kapalılık ve göğüs yüzeyi bakımından, hem doğal hem de yapay yolla kurulmuş genç meşcerelerin 20-30'lu yaşlarda, yaşlı doğal meşcerelerin özelliklerine ulaştığ 1 görülmüştür. Hacim olarak ise biraz daha fazla süreye ihtiyaç bulunduğu anlaşılmaktadır. Bu durumda, yani yaş lı orman alanlarının gençleştirilmesiyle, orman ekosisteminde tutulan karbon miktarında belirli bir süre (yaklaşık 60 yil) bir azalma meydana geldiği söylenebilir. Diğer yandan, bozuk alanların odun üretimi bakımindan verimli hale getirilmesi, yani ağaçlandırılmasıyla, tutulan karbon miktarında çok önemli bir artış olmaktadır. Bir bakıma doğal gençleştirme çalışmalarıyla oluşan boşluk, ağaçlandırmalarla telafi edilmektedir. Son 50-60 yıl içinde kızılçam ekosistemlerinde yürütülen ağaçlandırma ve rehabilitasyon çalışmaları gözönünde bulundurulduğunda, bu güne kadar yapılan işletmecilik faaliyetlerinin karbon tutulumunu olumsuz olarak etkilemediği ifade edilebilir.

Ekolojik verimliliğin göstergelerinden birisi olan meşcere zeminindeki döküntü ve humus tabakas1, toprağın verimliliği ve besin döngüsü açıs indan önemlidir (Özkan, 2004; Prescott, 2005, Özkan vd. 2008; Özkan ve Gülsoy, 2009; Özkan, 2010). Ayrıca döküntü ve humus tabakas1 birçok organizmaya (mantar, bakteri, örümcek, solucan, semender, kuş, sürüngen, böcek vs) habitat sağlamaktadır (Uetz, 1979; Haila ve Niemelä, 1999). Yaşlı doğal kızılçam meşcereleri temel alındığında, doğal gençleştirme çalışmalarının döküntü ve humus tabakasını tahrip ettiğ $i$ görülmektedir. Yeni kurulan meşcerelerdeki döküntü ve humus miktarı, yaşlı meşcerelerde bulunan miktarın, 12 yaşında yaklaşık \%30'una, 23 yaşında \%36'sına ve 34 yaşında \%52'sine karşıllk gelmektedir. $\mathrm{Bu}$ oranlara bakıldığında, meşcere yaşı arttıkça döküntü ve humus miktarında belirgin bir artışı gerçekleştiği gözlemlenmektedir. Ancak, yaş lı meşcerelerdeki döküntü ve humus miktarına ulaşmak için daha fazla zamana ihtiyaç bulunmaktadır. A ğaçlandırma yoluyla kurulan meşcerelerde zeminde biriken döküntü ve humus miktarının da giderek arttığ1 görülmektedir. Özellikle bozuk kızılçam meşcerelerle klyaslandığında, döküntü ve humus miktarı, örneğin 30 . yaşlarda yaklaşık 2,5 kat bir artış göstermiştir. Bu artış, bozuk sahaların ağaçlandırılmasının, döküntü ve humus tabakasını kullanan organizmalar için önemli olduğuna işaret etmektedir. Diğer yandan, ağaçlandırma sahaları ve doğal gençleştirme sahaları arasında, döküntü ve humus miktarı bakımından çok önemli bir fark göze çarpmamaktadır. Bu sonuç, Tullus vd. (2013) tarafindan doğalgençleştirme ve ağaçlandırma yoluyla kurulmuş kayın meşcerelerinde yapılan araştırmanın bulgularıly da uyumludur.

Diğer taraftan, üst topraktan $(0-5 \mathrm{~cm})$ alınan örneklerdeki karbon oranları incelendiğinde, doğal gençleştirme yoluyla elde edilmiş meşcerelerin, yaşlı meşcerelerdeki koşullara daha erken yaş larda ulaşılabileceği söylenebilir. Ayrıca, benzer yaştaki ağaçlandırma ve doğal gençleştirme sahaları arasında, doğal gençleştirme sahalarının lehine, karbon oranı bakımından yaklaşık iki kat fark bulunmaktadır. Bunun sebebi, ağaçlandırma sahalarında yürütülen toprak işleme çalışmalarının üst toprak tabakasını etkilemesi olabilir. Doğal gençleştirme sahalarında ise, başlangıçta toprakta zaten belirli oranda organik maddenin bulunmas1 ve kesim artıklarının serilmesi gibi faktörler sebebiyle, üst toprak tabakası nispeten daha az etkilenmektedir.

Ülkemiz kızılçam orman ekosistemlerinde, orman zemininde kalın ölü odun enkazına rastlamak oldukça güçtür. Oysa biyolojik çeşitliliğin zenginleştirilmesi ve sürdürülmesi için, farklı çürüme sinıflarındaki kalın ölü odunların, sağlıklı bir ormanda belirli bir oranda bulunması gerektiği bilinmektedir (Sullivan vd. 2012). Kalın ölü odunlar, yakacak ihtiyacı için orman köylüsü ya da böcek zararına yol açacağı endişesiyle orman idaresi tarafindan sürekli toplanmaktadır. Zaten bilinen bu durum, çalışmayla da bir kez daha ortaya koyulmuştur. Grafikte görüldüğü gibi yaş 1 doğal meşcerelerde bile kalın odun enkazı miktarı çok azdır (Şekil 4). Bu sebeple, çalışmada, kalın odun enkazı ile ilgili bir değerlendirme yapmak mümkün olmamıştır. Diğer taraftan, doğal yöntemlerle kurulmuş meşcerelerde benzer yaștaki ağaçlandırma sahalarına oranla daha fazla ince ölü odunun bulunduğu görülmektedir. Her iki gençleştirme yöntemiyle kurulmuş meşcerelerde de, bakım kesimleri sebebiyle, 20'li yaşlarda ince ölü odun miktarının en fazla olduğu fakat bu yaşlardan sonra, bu miktarın azaldığ anlaşılmaktadır. Ölü odun ve çalı yığınları, yaban hayatı için çok değerli olduğundan (Sperry ve Weatherhead, 2010; Goguen vd. 2015), bakım kesimleri sonucu oluşan ince odun yığınlarının bulunduğu genç meşcerelerin, kızılçam orman ekosisteminin habitat çeşitliliğine önemli katkı sağladığ1 söylenebilir.

Odunsu tür zenginliği, meşcere tepe çatısının düşük olduğu meşcerelerde en yüksek bulunmuştur. Doğal gençleştirme sahaları, ilk yıllarda, çok sayıda çalı türüne ev sahipliği yaptığından, bulunduğu ekosistemde meşcere çeşitliliğini arttırdığ 1 ve bu bakımdan bu alanların biyolojik çeşitliliğin korunmasında önemli rol oynadığ düşünülmektedir (Keenan ve Kimmins, 1993). Bozuk kızılçam meşcereleri ve makilik alanların ağaçlandırmasının ise, çalı türü zenginliğini düşürdüğü ve önemli habitat kayıplarına yol açtığı anlaşılmaktadır.

Sonuç olarak, Akdeniz kızılçam orman ekos is temlerinde uygulanan doğal gençleştirme ve ağaçlandırmaların, hem olumlu hem de olumsuz etkilerinin bulunduğunu söylemek mümkündür. Altı çizilmesi gereken önemli bir husus; doğal gençleştirme çalışmalarının bazı yaş lı meşcere özelliklerinin yitirilmesine sebep olmasıdır. Diğer taraftan, ülkemiz yapacak odun ihtiyacının önemli bir bölümünü sağlayan kızılçam türünde, mevcut doğal gençleştirme uygulamalarının devam ettirilmesi kaçınılmazdır. Dolayısıyla, bu olumsuz etkinin azaltılması ve alternatif silvikültürel sistemlerin geliştirilmesi yoluna gidilmelidir (Baskent vd. 2008). Bu konuda atılacak en etkili adım, belirli oranda yaşlı doğal meşcerenin dokunulmadan ormanda bırakılmasıdır. Ağaçlandırma yoluyla kurulan yeni meșcereler, orman ekosisteminde tutulan karbon miktarını arttırmak suretiyle küresel iklim değişimi üzerindeki olumlu rolünün yanıs sra, yaban hayvanlarına çeşitli habitat imkânı sunan ve birçok endemik bitki türünü barındıran makilik ekos is temlerin azalmas ina yol açmaktadır. Bu yüzden, odun üretimi bakımından birinci bonitet sahalar dışında, makilik alanlarda uygulanacak ağaçlandırmalar kısıtlanmalıdır. Özellikle, toprak koruma, biyolojik çeşitliliği koruma, estetik, tabiatı koruma, su koruma gibi orman fonksiyonları için önemli görülen ve kızılçam ormanlarında çeşitliliği 
artıran, yoğun çalı ve ağaççıklarla kaplı makilik alanların korunması çok önemlidir.

\section{Teşekkür}

$\mathrm{Bu}$ çalışma, kısmen Süleyman Demirel Üniversitesi, Bilimsel Araştırma Projeleri Koordinasyon Birimi tarafindan desteklenmiştir (SDÜ-01070 no'lu güdümlü proje). Çalışmanın laboratuvar çalışmalarında yardımeı olan, SDÜ Ziraat Fakültesi öğretim üyesi Dr. Hüseyin Şenol'a ayrıca teşekkür ederiz.

\section{Kaynaklar}

Akdemir, D., Özdemir, İ., 2015. Batı Akdeniz Bölgesi'ndeki kızılçam ormanlarında uygulanan tıraş lama kesimlerinin kuşlar üzerindeki etkileri. Turkish Journal of Forestry, 16(2):102-110

Baskent, E. Z., Terzioğlu, S., Başkaya, Ş., 2008. Developing and implementing multiple-use forest management planning in Turkey. Environmental management, 42(1):37-48.

Deal, R. L., 2007. Management strategies to increase stand structural diversity and enhance biodiversity in coastal rainforests of Alaska. Biological Conservation, 137(4):520-532.

Eler, Ü., 2003. Dendrometri. Süleyman Demirel Üniversitesi Yayınları, Isparta.

Fırat, F., 1973. Dendrometri. İ.Ü. O.F. Yayınları, Kurtuluş Matbaas1, İstanbul.

Gerzon, M., Seely, B., MacKinnon, A., 2011. The temporal development of old-growth structural attributes in second-growth stands: a chronosequence study in the Coastal Western Hemlock zone in British Columbia. Canadian Journal of Forest Research, 41(7): 1534-1546.

Goguen, C. B., Fritsky, R. S., San Julian, G. J., 2015. Effects of Brush Piles on Small Mammal Abundance and Survival in Central Pennsylvania. Journal of Fish and Wildlife Management, 6(2):392-404.

Haila, Y., Niemelä, J., 1999. Leaf litter and the small-scale dis tribution of carabid beetles (Coleoptera, Carabidae) in the boreal forest. Ecography, 22(4):424-435.

Halpern, C. B., Spies, T. A., 1995. Plant Species Diversity in Natural and Managed Forests of the Pacific Northwest. Ecological Applications, 5:913-934.

Keenan, R. J., Kimmins, J. P., 1993. The ecological effects of clear-cutting. Environmental Reviews, 1(2): 121-144.

Lugo, A. E., 1992. Comparison of tropical tree plantations with secondary forests of similar age. Ecological monographs, 62(1): 1-41.

Lust, N., Muys, B., Nachtergale, L., 1998. Increase of biodiversity in homogeneous Scots pine stands by an ecologically diversified management. Biodiversity \& Conservation, 7(2): 249-260.
McElhinny, C., Gibbons, P., Brack, C., Bauhus, J., 2005. Forest and woodland stand structural complexity: its definition and measurement. Forest Ecology and Management, 218(1): 1-24.

Oğurlu, İ., 2008. Yaban hayati kaynaklarimizin yönetimi üzerine. Süleyman Demirel Üniversitesi Orman Fakültesi Dergisi, A(2): 35-88.

Odabaş1, T., Özalp, G., 1994. Ormanların işletilmesi yöntemleri ve doğaya uygun ormancıllk anlayışı. İ.Ü. Orman Fakültesi Dergisi, 44(1-29): 35-47.

Prescott, C. E., 2005. Decomposition and mineralization of nutrients from litter and humus. In: BassiriRad, H. (Ed.), Nutrient Acquisition by Plants, Springer Berlin Heidelberg, pp. 15-41.

Özkan, K., Gulsoy, S., 2009. Effect of environmental factors on the productivity of crimean pine (Pinus nigra ssp. pallasiana) in Sutculer, Turkey. Journal of Environmental Biology, 30(6): 965-970.

Özkan, K., 2004. Beyşehir Gölü Havzası'nda Anadolu Karaçamının (Pinus nigra Arnold) Yayılışı ile Fizyografik Yetişme Ortamı Faktörleri Arasındaki İliş kiler, Turkish Journal of Forestry, 2:30-47.

Özkan, K., 2010. Orman ekosistemçeșitliliği haritalama çalışmaları için ekolojik alan çeşitliliğinin belirlenmesi üzerine bir öneri. Turkish Journal of Forestry, 2:136148.

Özkan, K., 2010. A succesion for determination of ecologic area diversity index for forest ecosystems diversity mapping. Süleyman Demirel Üniversitesi Orman Fakültesi Dergisi,, 2:136-148.

Özkan, K., Gülsoy, S., Mert, A., 2008. Interrelations between height growth and site characteristics of Pinus nigra Arn. ssp. pallasiana (Lamb.) Holmboe. The Malaysian Forester, 71:9-16.

Sperry, J. H., Weatherhead, P. J., 2010. Ratsnakes and Brush Piles: Intended and Unintended Consequences of Improving Habitat for Wildlife? The American Midland Naturalist, 163(2):311-317.

Sullivan, T.P., Sullivan, D.S., Lindgren, P.M.F., Ransome, D.B., 2012. If we build habitat, will they come? Woody debris structures and the conservation of forest mammals. Journal of Mammalogy, 93:1456-1468.

Tullus, T., Tullus, A., Roos aluste, E., Kaasik, A., Lutter, R., Tullus, H., 2013. Understorey vegetation in young naturally regenerated and planted birch (Betula spp.) stands on abandoned agricultural land. New Forests, 44(4):591-611.

Uetz, G. W., 1979. The influence of variation in litter habitats on spider communities. Oecologia, 40(1):29-42. 